\title{
Challenges Faced By SME's In South Africa: Are Marketing Skills Needed?
}

Michael Cant, University of South Africa, South Africa

\begin{abstract}
In South Africa the SME sector has been placed on the government's priority list for economic assistance and job creation. The government expects 500000 jobs to be created every year for the next 10 years - the bulk which is expected to come from the SME sector. Research conducted by Bowler, Dawood and Page (2006) and Phakisa (2009) estimate that 40\% of new business ventures fail in their first year, 60\% in their second year, and 90\% in their first 10 years of existence. There are numerous reasons for these failures and many authors have identified the challenges these businesses face. The research problem of this study emanates from the current high business failure rate as well as the lack of and need for marketing skills of South African SME managers. The research investigates the correlation between business success and the need for marketing skills and to what extent the lack of these skills influence the failure or success of the business. The research made a direct link to the lack of marketing skills and the failure of businesses as well as the fact that managers and owners are aware of these shortcomings that they have. The conclusion is that there is a positive correlation between the success of a business and the need for marketing skills in South African SME's. The challenge that now faces government, educational institutions and businesses themselves is to develop these marketing skills in such a way that the chances of survival of these SME's are increased.
\end{abstract}

Keywords: Small Business; Marketing Skills; Economic Survival; South African Business Failure

\section{INTRODUCTION}

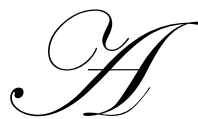

ccording to various authors (Bowler, Dawood \& Page, 2006; Phakisa, 2009) it is not sensible or possible to really have one globally acceptable definition for a small business. This can mainly be attributed to the differences in the composition of the economic sectors of countries as well as the populations' cultural differences that exist between countries. A small business in Germany or the USA may for instance be classified as those businesses employing less than 200 people, or a turnover of less than $\$ 50 \mathrm{~m}$ while in South Africa this may be classified as a large business. It therefore stands to reason that the definition of a small business in Australia and South Africa will be vastly different than their bigger counterparts in the US and the EU. In South Africa Phakisa (2009) defines an enterprise with less than 100 employees to be an SME (Small Medium Enterprise).

It is estimated that small business undertakings create about $80 \%$ of all new job opportunities and according to Bowler, Dawood and Page (2006) more than $70 \%$ of all South Africans are employed in the small business sector. The government has identified small businesses as the way forward to create jobs and to stimulate economic growth in order to combat the huge number of unemployed youth in the country - which is currently at 30\% (2012). Nager, Swanepoel and van der Merwe, (2008: 37) indicated that small business development should be an essential component of all reconstruction and development initiatives and this has the potential to economically empower the majority of the country's people. Even though SME's have a major role to play in economic development it must be noted that the failure rate of SME's are extremely high and will not be the solution to these problems unless it is managed well and they are assisted in their overall management actions. Pearce and Byars (2002) indicated in their research that nearly $40 \%$ of new business ventures fail in their first year, a further $60 \%$ in their second year, and $90 \%$ in their first 10 years of existence. A main reason for conducting this investigation is due to this high incidence of failures and to try and identify reasons and causes that may help in alleviating these 
failures. Secondary resources such as Dockel and Ligthelm (2002), Cant and Ligthelm (2002) have indicated that either no or limited marketing is undertaken by SMEs in general which can be a contributing factor to the high failure rate of SME's in South Africa. Kroon and Moolman (2007) indicate that due to the high start up costs of SME's, marketing is usually not given a priority but rather seen as an expense - and therefore neglected.

This study poses the question if marketing skills are important and to what extend South African SMEs managers have these skills. In this regard, the problem to be researched is the need for marketing skills amongst SME's. The focus will therefore be on the correlation that may exist between the need for marketing skills of SME's and the potential for success.

\section{Problem statement}

In general when a business fails, and by implication SME's, the focus is on the financial skills and issues and usually not on other issues. It is mostly assumed that businesses fail due to a lack of cash flow, or not enough revenue without thinking of the other contributing aspects to such a situation. This study will focus on the marketing issues, and more specifically marketing skills, of SMEs. In this regard, the problem to be addressed will be on a lack or even incorrect marketing actions by SME's. This can and will contribute towards the failure of a business and therefore warrants attention. This approach is underscored by amongst others Bateman and Snell (2006) when they argue that they realised something was wrong with the business as the opportunities identified did not match the results they expected. They found that businesses generally could not sustain themselves due to a lack of sufficient cash reserves, and that sales were not enough to generate cash flow due to amongst others a lack of marketing skills or management was ineffective.

\section{Specific aims of the research}

The specific objectives of the study were to obtain feedback on the need for marketing skills amongst SME owners, and to establish whether an absence of these skills have an impact on the success of SME's perceptions of the importance of marketing for SMEs in South Africa.

In order to attain the objective of this paper, the following hypothesis was formulated.

$\mathbf{H}_{1}$ : There is a positive correlation between the success of SME's and the marketing skills needed by SME owners or managers.

\section{LITERATURE REVIEW}

\section{Marketing and SME's - An African perspective}

It is a generally accepted fact that small business owners or managers are responsible for a wide range of tasks in the business - if not everything in the business. The implications of this, is that certain tasks will receive more attention than others and needless to say some will be neglected. In some businesses financial aspects will receive preference, in others it will be stock control and in others again it may be sales. Unfortunately business owners - especially in the case of SME's - cannot afford to only focus on what they like. They still have to perform all the tasks. So even if the owner does not like marketing for example, they still need to perform the tasks associated with marketing and therefore need the marketing skills. Managers need some marketing skills to ensure that there is balance in their business' (Bowler, Dawood \& Page, 2007). It stays a fact that the marketing actions in the business will influence the long term survival of a business - if it does not directly affect the overall success and survival of the business. It is common sense that if your target market, i.e. customers, are not aware of what you offer, where you are located, or what your total product offering includes they cannot support the business. Gem (2002) argues that marketing in SMEs is fundamentally different from the marketing conducted by larger businesses, as they face different challenges. This is partially ascribed to the fact that the decisions taken by marketers in SME's and the implementation thereof can be more important to the success of the business than planning and strategy. 
Walker, Boyd and Larreche (1999) argue that a major factor in the success or failure of a marketing or business strategy at any level is whether it fits the realities of the organisation's external environment. Thus, in order to be able to develop a marketing strategy for a product, or the business as a whole, the SME owner need to ensure that he/she has a clear understanding of the factors in this environment that can and will influence the business - that means identifying the opportunities and threats in the environment. Kotler (2005) furthers this argument in his contention that the key to successful strategic marketing is focusing, positioning and differentiation. The company (SME) must define its target market carefully and based on its understanding of the needs of the market and the perceived environmental influences. To be successful the business must focus on a specific market segment, position itself in the minds of the consumers, the best solution to their needs in that specific case, and use any relevant and important tool to differentiate itself from its competitors. The SME must also try and develop valued points of difference in its offerings and services that competitors would find difficult to copy.

Research by Smit (1999) showed that many SMEs failed because they lacked an understanding of the relevance and importance of marketing in their businesses. However, Smit (1999) did not investigate the underlying reasons for this phenomenon. This study attempts to identify the major challenges facing the business regarding marketing skills needed by SME's.

\title{
Marketing skills
}

Murphy (2006) states that small business owners exhibit certain personality traits that are responsible for the success or failure of their businesses and that inadequate marketing skills of owners create sustainability and survival problems in the small business sector. Therefore it is argued that if the small business owner does not possess the required skills or have the knowledge regarding marketing issues and how to apply these skills and knowledge it can and will lead to the demise of the business - or at best that it will not become as profitable as it can become. Even though all functions and tasks are important the marketing function is the only one that generates income for the business and therefore the success of the business largely depends on the marketing skills being applied in the business.

\section{Marketing skill challenges of SMEs}

Some of the studies already alluded to as well as others have identified a list of marketing skill challenges facing SMEs. When categorised, these challenges can be related to the following:

\author{
- $\quad$ To gain an understanding of the market and potential for growth \\ - $\quad$ Market Segmentation \\ - $\quad$ Market Needs Analysis \\ - $\quad$ Access to finance to fund marketing actions \\ - $\quad$ Education and training \\ - $\quad$ Competitiveness \\ - $\quad$ Marketing of products and services
}

It is clear from the list above that in order to give adequate attention to marketing issues the marketer or entrepreneur requires certain marketing skills. It can be accepted that marketing is one of the most important tasks a SME has to perform and in order to do this the skills needed for this purpose include an understanding of marketing activities, sales, increasing market share to introducing particular new products or building relationships with customers Table 1 indicates the importance of the stated needs of an SME from a business and marketing skills development perspective. Table 1 indicates, a proper understanding of business and marketing skills are regarded as either critical (30\%) or somewhat important (59\%) by businesses, for growth and success of SMEs. Furthermore, a total of $70 \%$ of the respondents in that study indicated staff training to be either critical or somewhat important compared to $75 \%$ who regard continuous learning as critical or somewhat important. Resources to hire professional advisors (24\%); more staff training (17\%) and a continuous learning philosophy (25\%) are all regarded as being critical to ensure business success. 
Table 1: How important are the following needs of an SME from a business skill development perspective?

\begin{tabular}{|lcccc|}
\hline Need & Critical & $\begin{array}{c}\text { Somewhat } \\
\text { important }\end{array}$ & $\begin{array}{c}\text { Not very } \\
\text { important }\end{array}$ & $\begin{array}{c}\text { Not at all } \\
\text { important }\end{array}$ \\
\hline Better knowledge of business and marketing skills (\%) & 30 & 59 & 10 & 1 \\
Resources to hire professional advisors & 24 & 46 & 22 & 7 \\
More staff training & 17 & 53 & 26 & 5 \\
A continuous learning philosophy & 25 & 50 & 20 & 5 \\
\hline
\end{tabular}

Source: CMA Canada.

\section{Measurements of successful SMEs}

The success of SMEs can be measured with the following measures:

- $\quad$ Profitability is probably the first thing people think about when measuring success.

- $\quad$ Growing customer base is a sure sign that the SME is effectively reaching target markets.

- Customer satisfaction is an indication that the SME understands the needs of customers.

- $\quad$ Employee satisfaction is another key indicator of business success.

- Owner satisfaction.

\section{METHODOLOGY}

Secondary and primary sources were consulted in order to gather information regarding the managerial skills of small business owners. The main sources consulted include journals, articles, press reports, books and research studies.

As the aim of the research was to establish the need for marketing skills of SME managers and owners, a qualitative paradigm was deemed appropriate for the primary research. The population of the research consists of all registered small business owners in South Africa. A Department of Trade and Industry (DTI, 2007$)$ list of 10 000 small business owners was available and served as the basis for the study. A sample of 1000 small business owners was randomly selected from this list and the 1000 questionnaires were completed by means of personal interviews during February 2008. Of these a total of 801 completed questionnaires were regarded as usable representing an $80 \%$ response rate. Based on Nederhof (2002) this can be regarded as a satisfactory response rate considering the sensitivity of the topic, the nature of the problem under investigation and the inhibitions that management might have regarding the survey.

The main construct of this study was measured through the use of Likert-type scales. The basic scale design therefore consisted of a Likert-type scale with five scale points (with labels ranging from strongly agree to strongly disagree) and 11 scale items. This scale was found to be highly reliable with a Cronbach's alpha of 0.7 . In this study the researcher not only wants to describe the sample data such as means, standard deviation and proportions but wishes to make inferences about the population based on what was observed in the sample. Therefore the following null and alternative hypotheses were formulated:

$\mathrm{H}_{01} \mu 1=\mu 2$

$\mathrm{H}_{\mathrm{A} 1}: \mu 1 \neq \mu 2$

\section{FINDINGS}

\section{The impact of market related issues on the business}

The impact of market related issues on small business owners were measured in the questionnaire. Secondary research identified eight market-related issues, namely: Poor locality, ineffective marketing, lack of market knowledge, low product demand and increase in competition. The question tested whether any of the eight market-related issues are regarded as issues that can lead to business failure. Figure 1 presents the outcome of the survey findings. 


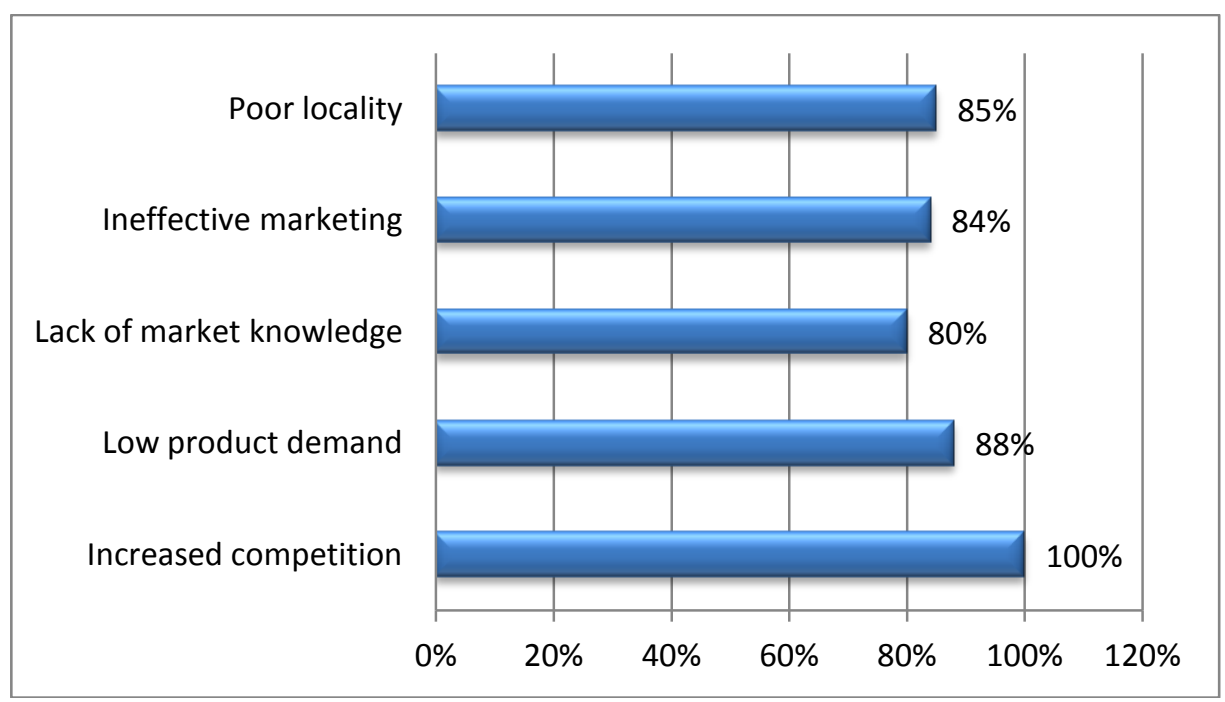

Figure 1: Impact of market related issues on business

Based on the findings it is clear that:

i. $\quad$ All the respondents see an increase in competition as an issue that will impact on business success;

ii. $\quad 88 \%$ indicated low demand for their products as issues that will have an impact;

iii. A significant $85 \%$ of respondents indicated poor location of the business as a factor that can have a serious impact;

iv. A further $84 \%$ of respondents were of the opinion that ineffective marketing will have an impact; and v. $\quad 80 \%$ of respondents saw a lack of marketing knowledge to have an impact.

The respondents believed that the above-mentioned factors can and will all contribute towards business failure. It is significant that these are all key issues and that they at least are aware of the impact these issues will have.

\section{The impact of enterprise-based related issues on the business}

Managerial skills and business knowledge are an indication of how well an entrepreneur can perform important tasks and activities related to the functions of a business. The respondents were asked in the questionnaire which managerial and marketing skills they lack to successfully run a business. The respondents indicated the following skills, they felt is needed: Managing personal stress, managing time, performance appraisal, motivating employees, managing conflict, solving problems, marketing, bookkeeping, record keeping, writing business plan and pricing. Figure 2 presents the outcome of the survey findings.

Figure 2 indicates that the respondents lack the following marketing and managerial skills:

i. Thirty seven percent of the respondents had problems establishing prices of products and services;

ii. Thirty one percent do not have the knowledge to record business transactions;

iii. Thirty one percent could not write a performance appraisal;

iv. Twenty nine percent experienced marketing problems;

v. Twenty six percent had difficulty managing conflict in the workplace;

vi. Eighteen percent had problems with time management;

vii. Sixteen percent experienced problems solving problems;

viii. Twenty one percent could not managed personal stress;

ix. $\quad$ Twenty percent experienced problems with book keeping;

x. Ten percent had problems motivating people; and

xi. Four percent could not write a business plan 


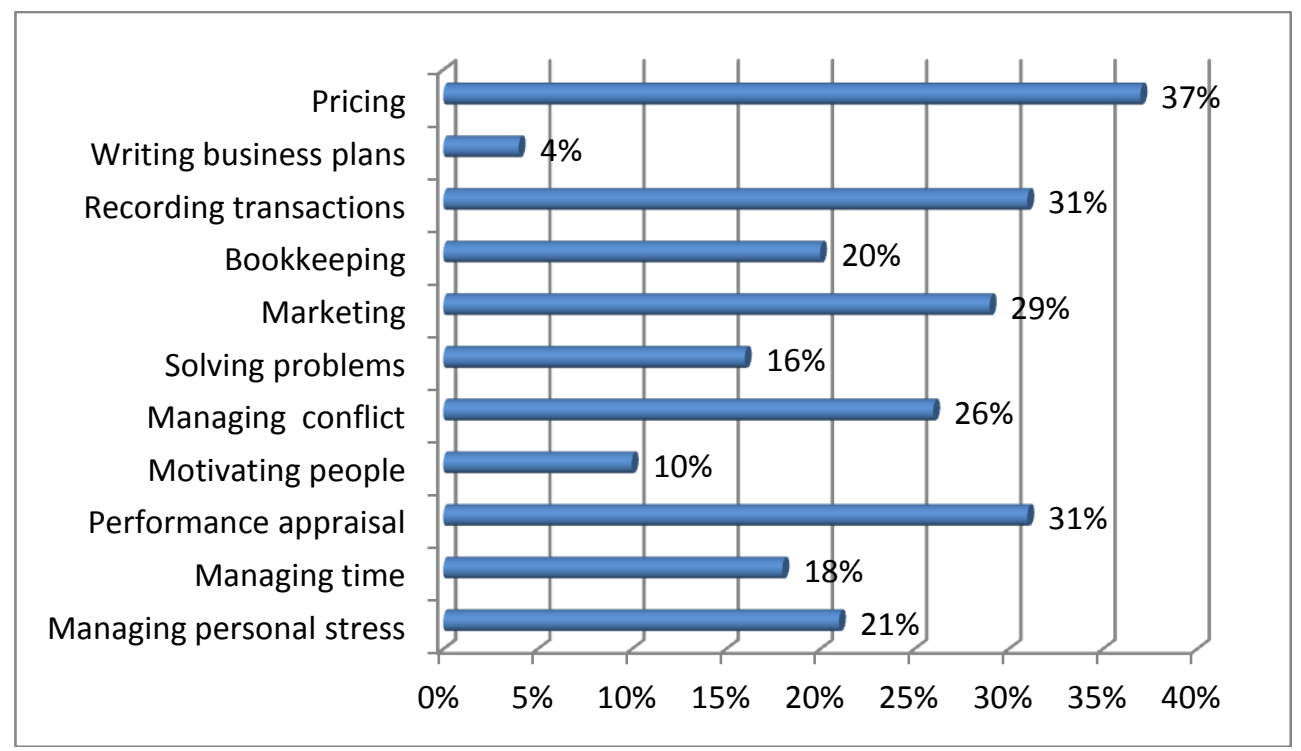

Figure 2: Managerial skills

The respondents were asked in an open-ended question to list the problems they faced in the efficient running of their business. The respondents listed the following issues: Crime, economic factors, finance, labour and rent. Figure 3 shows the responses.

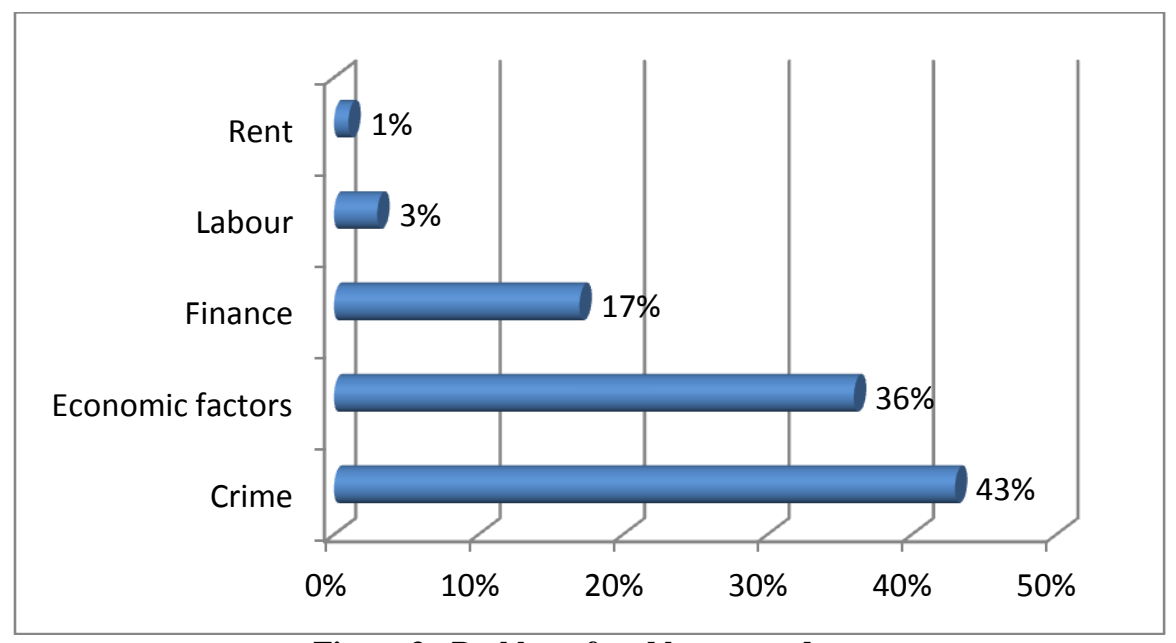

Figure 3: Problems faced by respondents

It is clear from the responses that the SME owners/managers regard crime (43\%) as the major stumbling block in the running of their business. It is clear from these responses that crime is something that can and will hinder the economic development of small businesses and that there is little that can be done from a business perspective to overcome these problems.

As indicated in Figure 3, 36\% of the respondents regarded economic factors as stumbling blocks. This is once again an uncontrollable factor by which businesses must adapt to. The downside is that the worst the economy is, the more people will lose their jobs resulting in further pressures on sales and a potential increase in crime. Seventeen percent of the respondents with existing businesses regard finance as a problem while $3 \%$ of the respondents indicated that they experienced problems with employees. Respondents agreed that crime and economic factors are the major factors that impact on the success of their businesses. 


\section{Factors contributing to small business failure}

Other factors that were investigated in this research project as having an impact on the failure of small businesses include the reasons why businesses failed and whether there is a relationship between lack of marketing skills and business failure.

\section{Reasons why businesses failed}

A number of reasons were proposed by respondents as to why businesses fail and two main reasons offered were a lack of marketing skills and financial problems experienced by businesses. It was interesting to note that a staggering $90 \%$ of the respondents were of the opinion that small businesses failure can be attributed to a lack of marketing skills. Seventy percent of the respondents, whose first business initiative failed, blamed financial problems as the main reason why the business failed. The results suggested that a lack of money for running expenses or expansion/capital items is a widespread problem facing small businesses. The net effect is insufficient funds to use to market the business.

\section{Relationship between lack of marketing skills and business failure}

The respondents were asked whether they believed that a positive relationship exists between a lack of managerial skills of small business owners and business failure in South Africa. As indicated in Figure 4, 74\% of the respondents believed that a positive relationship does exists between lack of marketing skills of small business owners and business failure in South Africa as opposed to only $26 \%$ who do not believe so.

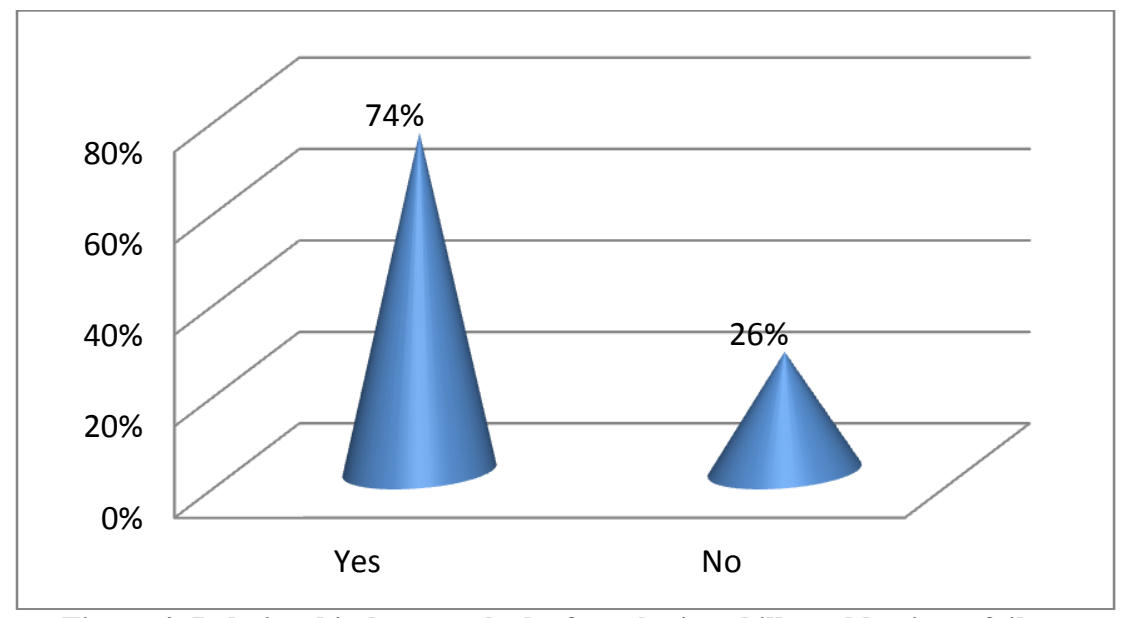

Figure 4: Relationship between lack of marketing skills and business failure

The aim of the research, as indicated earlier was to investigate whether lack of marketing skills is the main cause of business failure. The hypothesis formulated for this research is:

$\mathbf{H}_{\mathbf{0}}$ : There is a positive correlation between the success of SME's and the marketing skills needed by SME owners or managers.

To achieve the objectives of the study,

$\mathrm{H}_{01}: \mu 1 \neq \mu 2$

$\mathrm{H}_{\mathrm{A} 1}: \mu 1=\mu 2$

The response of the hypothesis is shown in Table 2 below. Table 2 shows that the Pearson correlation indicates a perfect correlation of 1 at a significant level of 0.052 -tailed. When conducting the $\mathrm{z}$-test, $\mathrm{H}_{01}$ was rejected thus accepting $\mathrm{H}_{\mathrm{a} 1}$. Therefore, by accepting $\mathrm{H}_{\mathrm{a} 1}$, one may conclude that there is a positive correlation between the success of SME's and the marketing skills needed by SME owners or managers. 
Table 2: The Pearson correlation

\begin{tabular}{|llcc|}
\hline Variable & & Lack of marketing skills & $\begin{array}{c}\text { Total: Lack of marketing } \\
\text { skills and business failure }\end{array}$ \\
\hline Lack of marketing skills & Pearson correlation Sig. (2-tailed) & 1 & 0.073 \\
& $\mathrm{~N}$ &. & 0.448 \\
& & 157 & 156 \\
Total: Lack of marketing & Pearson correlation & & 1 \\
skills and business failure & Sig. (2-tailed) & $\mathrm{N}$ & 0.073 \\
& & 0.448 &. \\
\end{tabular}

It is evident from the study that business owners' lack certain managerial skills such as marketing, financial, and personnel skills to operate their businesses successfully. The research findings confirm that small business owners are in need of support services such as training, counselling, and financial assistance in order to make their businesses more successful. It is equally evident that small businesses are constrained not only by financial factors but also specifically by non-financial factors such as lack of education in certain areas of business and marketing, inadequate technical skills, poor access to markets, lack of information and unreliable infrastructure. The analysis also indicates that the marketing skills that the respondents possess, and those that they preferably should have, do not correlate and that this presents a huge gap.

\section{Marketing challenges of SMEs}

The respondents were asked to indicate which specific marketing skills challenges they experience in the running of their business. Figure 5 shows the responses received from respondents.

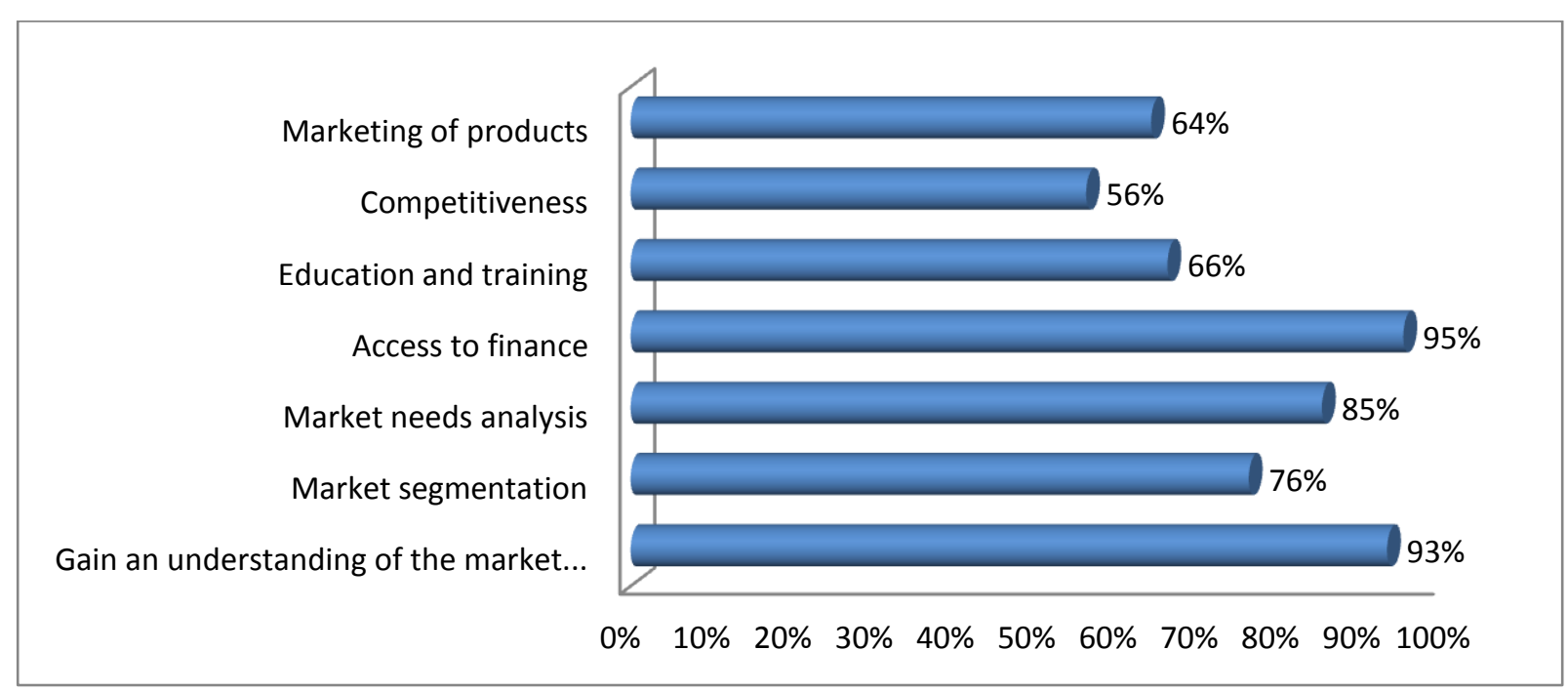

Figure 5: Marketing skill challenges

In Figure 5 the following challenges are raised by respondents and it is clear from these responses that there are major areas of improvement that must be addressed. From figure 5 the following is concluded:

i. Sixty four percent of the respondents experience marketing of products and services as a challenge.

ii. $\quad$ Fifty six percent of the respondents consider competitiveness as a challenge;

iii. Sixty six percent of the respondents experience education and training as a challenge;

iv. Ninety five percent of the respondents experience access to finance as a challenge

v. Eighty five percent of the respondents indicated the conducting of a market needs analysis as a challenge.

vi. Seventy six percent of the respondents experience market segmentation as a challenge

vii. Ninety three percent of the respondents experience understanding of the market and potential for growth as a challenge 
It seems that 'access to finance as a challenge' and'understanding of the market and potential for growth" are considered the main challenges for SMEs in SouthAfrica but the other issues raised are also high on the list of challenges and need to be addressed.

\section{RECOMMENDATIONS}

In order to survive and grow it is imperative that SME owners and managers design and develop marketing strategies for their business which will lead to the business growing and prospering. Small business success is based on the ability to build a growing body of satisfied customers. Modern marketing programs are built around the "marketing concept," which directs managers to focus their efforts on identifying and satisfying customer needs in such a way that a profit be realised. It is emphasised that marketing skills and business knowledge are an indication of how well an entrepreneur can perform important tasks and activities related to the successful running of their business. The marketing challenges of SMEs as identified in the study can be reduced by means of training these entrepreneurs in the marketing skills needed to make the business successful.

Based on the research of this study it is recommended that SMEs use the marketing concept and determine the following:

- What the needs of their customers are (Market Research);

- What their competitive advantages are (Market research and strategy);

- Which target markets to serve based on the strength and weaknesses of the business (Target Marketing), and

- What the best combination of products, services, location and promotional actions should be (Market Mix).

It is also crucial for the long term survival of the business to constantly evaluate its actions and to take the necessary corrective steps in order to adapt its marketing actions to the changing needs of their customers. This implied a focussed approach and a constant monitoring of changes in the needs of its customers, changing economic factors, and changes in the market regarding competitors.

\section{CONCLUSION}

The fact that SME owners used to survive without the necessary skills in marketing is long gone. The market in which businesses operate is constantly evolving and changing and it is the responsibility of the owner/manager to ensure that they stay in touch with these changes and upskill themselves in all areas ofbusiness and specifically marketing. They need to understand that the growth of the business by means of marketing actions is essential and that it is not only about survival - but also upliftment and economic development. The conclusion is that a positive correlation exists between the success of a business and the marketing skills needed and business failure in South Africa. The conducted research also indicated that marketing in the SMEs is the responsibility of the business owner/manager. The research established that marketing challenges of SMEs contribute to high business failure rate in South Africa.

\section{AUTHOR INFORMATION}

Professor Michael Cant is CoD of the Department of Marketing and Retail Management at the University of South Africa. He has published over 15 accredited articles in refereed journals and is the editor and author of more than 20 books in marketing. These books are widely prescribed at universities in South Africa. He has presented papers at more than 45 international conferences all over the world and is a well respected marketing and retail scholar. He holds a Ph.D. in Marketing from the University of South Africa. E-mail: cantmc@unisa.ac.za or cantm@woodlandsnet.co.za

\section{REFERENCES}

1. $\quad$ Bateman, T.S. \& Snell, S.A. (2006). Management: Building Competitive Advantage. $3^{\text {rd }}$ ed. Chicago: Irwin.

2. Bowler, A., Dawood, M.S. \& Page, S. (2007). Entrepreneurship and Small business Management. Pretoria: Juta \& Co. Ltd. 
3. Boyd, W. \& Larreche, M. (1999). Marketing Management: A Strategic Decision-Making employees. New York: McGraw Hill.

4. Cant, M. C. \& Lightelm, A. 2002. Small business problems in the South African context: a proactive entrepreneurial approach. [Online] available from:

http://iceb.nccu.edu.tw/proceedings/APDSI/2002/papers/paper233.pdf [Accessed: 2012-07-16].

5. Dockel, J.A. \& Ligthelm, A.A. (2002). Factors that contribute to small business survival. Article submitted for publication. Pretoria: Unisa.

6. DTI (Department of Trade and Industry). (Not dated). [Online] Available from: www.thedti.gov.za. [Accessed: 2007-03-12].

7. Gem. (2002). www.gem.org.za

8. Kroon, J., Moolman, P.L. (2007). Entrepreneurship. Pretoria: Kagiso Publishers.

9. Murphy, M. (2006). Small business management. London: Financial Times and Pitman Publishing.

10. Nager, T., Swanepoel, E. \& van der Merwe, M.A. (2001). Introduction to Entrepreneurship and Small business Management. Pretoria: UNISA Press.

11. Nederhof, K. (2002). Social research methods. London: Bacon.

12. Pearce, J.A. \& Byars, L.L. (2000). Management. New York: McGraw Hill. 